\title{
Resources
}

Ivo Balmer, Tobias Bernet

\section{Housing as a Common Resource? Decommodification and Self-Organization in Housing - Examples from Germany and Switzerland}

\section{Introduction}

Housing is something intimate. One could say that our homes represent a 'third skin' after clothing. Like clothes, shelter is regarded as a basic human need. Since this does not automatically translate into universal access in a less-than-perfect world, the provision of such basic goods is a fundamental political issue. A wide range of answers to the housing question have been developed in different times and places depending on the economic conditions and political hegemony. Both the market and the state have been hailed as the primary provider of housing and, even though the 'third sector' has mostly played a rather marginal role, there are noteworthy traditions of philanthropic and especially of self-help (cooperative) initiatives in housing.

The latter are certainly worth discussion in the context of the current 'rediscovery' of the commons, as is the field of public housing. In this chapter, we will attempt to sketch a typology of housing tenure and provision from a 'commons perspective,' examining to what extent housing can be seen as a common resource within different institutional arrangements. We will do this by analyzing a number of contemporary examples from Germany and Switzerland, two countries that are known as 'tenants' nations' by virtue of having some of the lowest rates of owner-occupied homes among industrialized countries, ${ }^{\mathrm{I}}$ and which thus represent a specific arena of marked contestations within the housing sector. Our analysis will follow the "analytical triad" that the editors of this volume put forth in defining the commons, ${ }^{2}$ following Exner and Kratzwald, ${ }^{3}$ Helfrich and Haas, ${ }^{4}$ and De Angelis and Stravrides,' among others, namely that: 


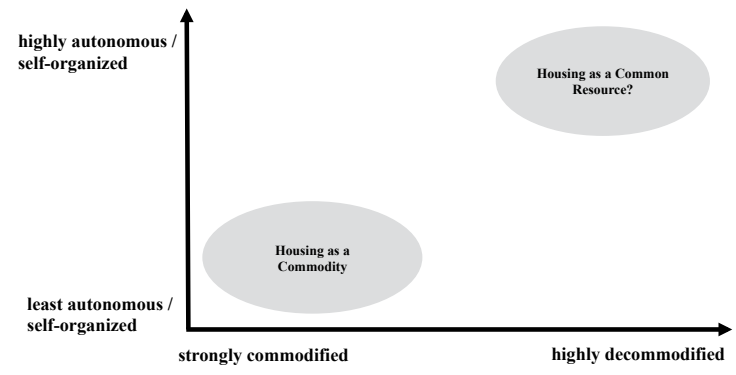

Figure I. Decommodification and self-organization: Two criteria to assess arrangements of housing Provision.

a) Housing is a basic urban resource, similar to infrastructure ${ }^{6}$ or land (but unlike the latter it is an 'artificial' resource,' and thus costly).

b) Different actors play different roles in any arrangement of housing provision. We may broadly speak of 'owners' and 'users' (e.g. tenants), but, following Peter Marcuse, ${ }^{8}$ we might be better off analyzing the specific 'incidents of ownership,' i.e. the rights, powers, privileges, and immunities which individuals, groups or organizations hold with regard to a dwelling. ${ }^{9}$

c) This 'bundle of rights' perspective points to the importance of institutions that regulate the allocation of housing. These mainly encompass I) property rights, and 2) public policies, i.e. legislative and financial interventions on behalf of the (welfare) state. ${ }^{10}$

Analyzing specific cases according to this 'commons triad,' we will consider two major points in order to assess the 'commons character,' or lack thereof, of any given mode of housing provision, as illustrated in Figure I.

First, we examine the extent to which housing is decommodified through a specific arrangement, i.e. how sustainably it is withdrawn from the sphere of profit-oriented, speculative real-estate markets. According to Andrej Holm, "decommodification, i.e. the withdrawal of housing provision from the market sphere, can be understood as the aim and the benchmark of housing policies and regulations." ${ }^{11}$ Hence, we focus on the relation between housing as a resource and the institutional framework (property rights or policies) that might prevent this resource from being treated as a commodity. In a commons-based arrangement, housing would have to correspond to De Angelis' description of "some sort of common pool of resources, understood as non-commodified means of fulfilling people's needs." 
Second, to bring into focus the relevant actors, we consider the level of autonomy or self-organization that the inhabitants enjoy, individually or collectively, as the users of the resource that their homes constitute. This means determining which opportunities they have to influence decisions concerning their homes, i.e. whether they fit De Angelis's definition of commoners "who share [...] resources and who define for themselves the rules through which they are accessed and used." ${ }^{13}$

In the next section (2) we will offer a brief outline of the specific qualities of housing as a unique type of good and its role in the capitalist economy. Following this, we will describe and analyze different legal and economic arrangements from both the public and the cooperative sector in relation to the two criteria just described with regard to public policies (3) and property rights (4). Our 'two-axis' approach aims to contribute to an understanding of "what a particular form of tenure really means." ${ }_{14}$ In the conclusion (5) we will reflect on the paths that commoning efforts in the housing sector can take in the complex contemporary 'late liberal' situation, in which neither the state nor the market are fully capable of offering satisfactory solutions for a just and sustainable provision of basic urban resources, yet in which both must inevitably be taken into account - and actively engaged - in the course of any struggle for the commons.

We will argue that, although demands for public policy interventions in the housing sector are still necessary and justified, one should take into account the fact that these types of welfare provisions have proven vulnerable to swift enclosure, i.e. privatization. In this light, creative 'hacks' of property rights may be the more promising path towards institutional arrangements that provide housing as a kind of common resource: "If [...] the components can be reduced to some basic enough common denominators [...] one should, procedurally, be able to rebuild quite different systems with different arrangements of the pieces." ${ }^{\text {"s }}$

\section{Housing as a unique kind of good and as a commodity}

In order to grasp what is at stake in the field of housing provision, it is crucial to consider a number of qualities that make housing a unique kind of good. First and foremost, housing is, as already mentioned, an absolutely essential, necessary good. Not having a home is considered to be a severe impediment to a dignified human existence. Consequently, housing is considered a basic human right according to 


\begin{tabular}{|c|c|}
\hline Owner-occupied Hosing & Rental Housing \\
\hline - ouright & Commercially Rented \\
\hline \multirow[t]{11}{*}{ - mortgaged } & - from small / privrae landlords \\
\hline & - from large / corporate landlords \\
\hline & Non-Profit Housing (“Social Rented”) \\
\hline & - public housing (government-owned) \\
\hline & - privately owned social hosuing \\
\hline & (government-subsidized) \\
\hline & - cooperative housing (government-subsidized \\
\hline & on some cases \\
\hline & - "philanthropc" non-profit housing (provided by \\
\hline & charitable foundations, religious organizations \\
\hline & etc.; government-subsidized in some cases) \\
\hline
\end{tabular}

Figure 2. Types of housing tenure and provision.

article 25 of the Universal Declaration of Human Rights. Secondly, housing is, in the vast majority of cases, the most immobile and, thirdly, the most durable of goods in modern capitalist economies. And, mainly because this durability makes it expensive to produce, it is, fourthly, also the most economically significant good in the life of most people, in that they spend more on it than on any other class of goods, be it via rent or via mortgages. ${ }^{16}$

This differentiation between renters and mortgage debtors points to what could be listed as the fifth particularity of housing: its institutional diversity, following Figure 2. "[W] hatever the constitutions of western countries might say [...], in general the populations of these countries do not have practical rights to housing by virtue of citizenship." ${ }^{17}$ In spite of its necessity, housing thus appears in various institutional guises' in the reality of contemporary capitalism. ${ }^{18}$ The same material object - a house (or an apartment) - can take on different legal and economic forms. It can be a state-provided benefit or, as we will attempt to show, something like a common good, however it is currently more often treated like a commodity.

The 'normal,' i.e. prevalent, type of housing tenure in the majority of industrialized countries is the owner-occupied home. ${ }^{19}$ By virtue of its 'personalization,' it might seem like a relatively strongly decommodified form of housing if one applies the well-known definition of Esping-Andersen, ${ }^{20}$ which posits that decommodification of a good or benefit means that one does not need to generate income in order to acquire, access, or maintain it. Yet perceiving decommodification as a measure of withdrawal of a good from market mechanisms, and in light of real-estate bubbles like the one in the United States that partly triggered the ongoing global 


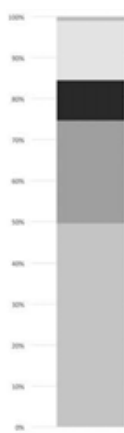

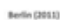



m mivate.

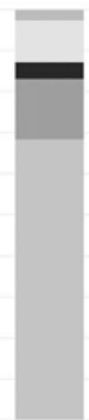

matavip

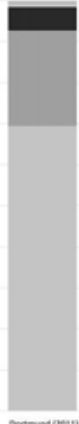

Dortmed gesi:

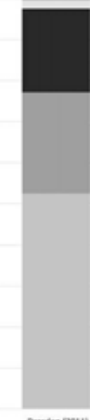

ombensat

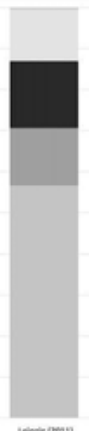

Lenewaent

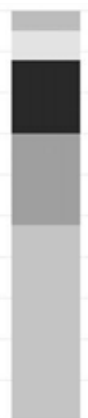

nenapoin]

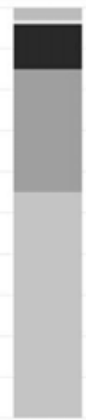

Anet trooel

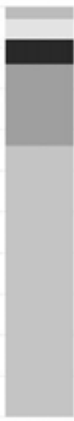

$\operatorname{mos} 10000$

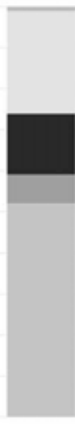

vemporiv

* Owner-occupied and rented out, ** Owned by municipal, Land/cantonal or federal authorities, *** Charitable foundations, religious organizations etc.

Figure 3. Types of housing tenure and provision in selected German and Swiss cities (and Vienna, Austria), in percentages. ${ }^{22}$

economic crisis, it is evident that owner-occupied housing is indeed utterly commodified nowadays, constituting an indebtedness-ridden mass market. Yet the position of the indebted homeowner is a very solitary one. In accordance with the phantasm of homo oeconomicus, to default on a mortgage seems like a personal failure, rather than the consequence of specific political and economic conditions beyond the individual debtor's control. ${ }^{21}$ It may be that the discrepancy between the needs of everyday life and the basic tendency of a capitalist economy is more obvious for tenants whose monthly payments not only cover maintenance and administration, but are, in most cases, also expected to yield a profit for the landlord. For-profit rental units, which, together with owner-occupied homes, make up the "commercial" housing sector, are the most common type of housing tenure in many urban areas. An illustration of the distribution of the various housing forms in the cases discussed can be found in Figure 3 .

The treatment of homes as an 'ordinary' commodity has often been questioned. As exemplified by recent tenants' struggles and 'right to the city' movements in various German cities, which have succeeded in extending beyond the usual leftist suspects, rising rents, and forced evictions, i.e. the tangible facets of gentrification continue to be capable of raising disquiet at a very basic level. ${ }^{23}$ Housing issues thus constitute an arena for passionate contestations of the status quo. 


\section{Decommodifying housing through public policies}

The insistence on housing's special status as a basic necessity, as articulated by social movements throughout the twentieth century, has brought forth institutions that provide housing which is, to some degree or another, decommodified. Examples can be found in many urban areas in the two countries this chapter focuses on. As with other necessary social goods, the state - in the case of housing often in the form of local governments - has mostly been seen as the foremost agent of such decommodification measures. These can take a variety of forms whose characteristics we want to explore in the following sections. We will first focus on public policies, such as subsidy schemes or zoning, and then turn to property-rights-related instruments.

\section{I Demand-side subsidies}

The least 'invasive' instruments in governments' surgical kits regarding housing provision are demand-side subsidies, which give people below a certain income-level money with which to pay their rent. In both Germany and Switzerland, these kinds of benefits are part of the standard ('income maintenance') welfare payment systems, and are regulated at the national level. In both cases, beneficiaries receive a separate payment for housing costs corresponding to their actual rent (whereas the basic monthly benefit for all other living costs is fixed). ${ }^{24}$ These welfare payments thus do not form part of any explicit housing regulation, even though they influence the residential sector in major ways. Many landlords who offer inexpensive housing, for instance, cater directly to welfare recipients, demanding the highest possible rent that welfare agencies will allow per square meter or per apartment, thus securing a steady source of revenue. At the same time, as recent studies have shown, ${ }^{25}$ demand-side subsidies tend to turn many centrally located districts into 'forbidden cities' for the welfare-dependent. The 'subject-based-support' approach thus fails to counter (and in part supports) the spatial segregation of different social groups which itself ultimately threatens the distinct qualities of 'the urban' that lie in "social differentiation without exclusion." ${ }^{26}$ Demand-side subsidies attempt to remedy an individual disadvantage without addressing the underlying question of how the allocation of a necessary good through market mechanisms can ever work 
for those lacking sufficient 'purchasing power.' Therefore, they certainly don't encourage arrangements that would provide housing as a common resource. And since the affected tenants are only regarded as market players, the issue of strengthening their autonomy and self-organization does not even come into view.

\subsection{Supply-side subsidies}

It thus seems evident that governments should consider intervening on the supply side of housing provision as well. Although housing has been called a "wobbly pillar" of the welfare state (compared with the classic trinity of health care, education, and income maintenance), ${ }^{27}$ there have indeed been major public efforts to provide decent and affordable housing for both the working and the middle classes, especially during the inter-war and the post-war periods. ${ }^{28}$ In the command economies of state socialist regimes such as the German Democratic Republic, the state directed virtually the entire housing and construction sector in a centralist, top-down manner. In the post-war heydays of expanding welfare states, this was to some extent paralleled by Western governments' housing programs. In the aftermath of World War II, West Germany funded the construction of 3.3 million homes in just a decade. ${ }^{29}$ Objektförderung, the subsidizing not of individuals' housing costs, but of "objects," i.e. buildings, can work in different ways. In both Germany and Switzerland, construction of affordable housing was mainly subsidized through low-interest loans as well as non-repayable ("à fonds perdu") contributions from government agencies at the local, Länder/Canton, and, in some instances, national level. In return, the owners of the newly constructed homes were obligated to subtract the subsidy from their "cost rent" (Kostenmiete - rent covering the costs of the capital taken up for the investment and running costs, including maintenance, but not yielding an additional profit), thus passing it on to the tenants. The make-up of rent prices is illustrated in Figure 4.

One core element of the (West) German social housing system (sozialer Wobnungsbau) that continued throughout the second half of the twentieth century was that subsidies were generally paid regardless of a building's ownership. Publicly owned corporations and cooperatives (see below) benefited from this system, yet so did private (individual or corporate) owners who were left to do with their property as they pleased once the contractually agreed subsidy period was over. This system of 
Capital costs (interest and amortizement)

Maintenance and administrative costs

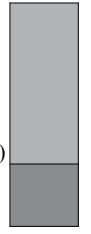

Cost Rent

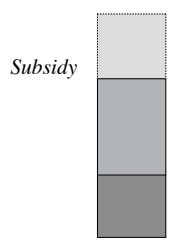

Subsidized Rent
Figure 4. Composition of rent prices.

"social housing as temporary occupation" $3 \circ$ was, after numerous cutbacks starting in the 1980 s, de facto ended on the federal level in $200 \mathrm{I}^{3 \mathrm{I}}$ and continues only in heavily downsized forms in the Länder. It came to be regarded as notoriously prone to inefficiency and downright corruption, since it contained no real incentives to keep production and administration costs low. It yielded absurd arrangements in some cases, notably in (West) Berlin, where the rents in some (formerly) subsidized estates are now above average while private or corporate owners and banks have been making handsome profits. ${ }^{32}$ Considering that the subsidized units are destined from the outset to revert into regular, commercially rented homes in this type of arrangement, it offers at best a temporary barrier to the commodification of housing (while breeding its own brand of speculation). And as it supports housing providers regardless of their general purpose and organizational set-up (profit-oriented and hierarchical as well as non-profit and participatory entities), it entails no particular promotion of inhabitants' self-organization either.

\section{$3 \cdot 3$ Zoning}

Apart from implementing (demand- or supply-side) 'market intervention' policies, governments can also facilitate the provision of affordable housing through their administrative powers. Recent amendments to a number of local zoning laws in Switzerland present one interesting example in this regard..$^{33}$ Thanks to regulation similar to what is known in the United States as "inclusionary zoning," municipalities can proscribe a percentage of 'affordable' housing (in the 'cost rent' sense 
described above) for all new or redeveloped residential buildings within areas whose land-use designations are changed, allowing for higher building density. Although housing affected by such regulation might be in the possession of owners who pursue a strongly profit-oriented strategy elsewhere (as with the 'non-affordable' part of the development in question), this form of development is decommodified to some extent in the sense that the specific 'incident of ownership' that gives the owner the right to ask for payments for its use by others is restricted - as long as this zoning law is in place. Examples of such projects show that real-estate developers tend to strike a deal with non-profit organizations that acquire part of the lot through leasehold (Baurecht) and take over construction and management of the "affordable" part of the development. Since these are often cooperatives organized on a membership-basis (see below), this type of zoning may indirectly foster dwellers' self-organization.

\section{Decommodifying housing through property rights}

While the policies described so far may influence the provision of affordable housing to a notable degree, they can be changed, watered down, or abandoned. Arrangements primarily regulated through government policies are subject to the political zeitgeist. In contrast, property rights in a narrower sense are consistently respected in capitalist democracies, regardless of current political majorities. Instruments that are directly linked to the property rights system might thus be capable of decommodifying housing in a more sustainable way and guaranteeing dwellers' self-organization in the long run.

\section{I Public housing}

Public housing in a strict sense, being the property of municipalities themselves, continues to play a significant role in many German and Swiss cities, as elsewhere, with local authorities being in possession of up to is percent of the total housing stock (please see Figure 3). ${ }^{34}$ In the current German discourse, it is often favorably compared by those who advocate decommodification of housing stocks to the Objektförderung model described above. (Neo-)liberals, on the other hand, often crit- 
icize governments' direct involvement in a sector that can be a highly profitable part of the capitalist economy.

Yet ideally, well-built and well-managed rental housing is financially self-supporting, i.e. the revenue generated through rents should cover the costs of the capital used to pay for its construction (and, if applicable, for land purchase), as well as administrative and maintenance costs. Public housing thus need not cost a municipality anything per se and might, in the long run, become a valuable asset. Publicly owned homes produced in this manner count as 'affordable housing' in the sense that they are rented out at cost rent (see above). Due to production costs, however, they are usually not particularly inexpensive for decades after construction. This segment of public housing can thus be regarded as targeting a 'broad segment' of the population, including the middle classes. Only some municipalities, usually ones with a strong social democratic tradition, adhere to this 'broad' public housing approach, but this includes some of the major cities in German-speaking Europe.

A well-thought-out public housing system which goes beyond this residual supply to cater to broader parts of the population, rather than only those in the direst need of support, can be said to provide housing in a manner that exhibits a considerable degree of decommodification. Yet this is only the case as long as the local government provides the necessary organizational means and refrains from cashing in on its public housing stock by selling it to either the inhabitants (as in the UK case of the Thatcher government's "right to buy" scheme), thus turning public dwellings into owner-occupied ones, which are theoretically resalable and thus commodified property, or even directly to corporate investors. We have lumped public housing in with those institutions that are linked to the property rights system, yet because this one very powerful incident of ownership - the right to sell lies with (local) governments, it is, in fact, subject to similar threats of enclosure as dwellings within the mainly policy-influenced arrangements described earlier. In other words, just because city-owned homes are not destined to be automatically converted into for-profit rentals (as in the case of the German subsidy scheme described above), they can still be privatized by a decision of the local legislative body, which is exactly what happened in the past few decades to hundreds of thousands of apartments in German cities. ${ }^{35}$ Furthermore, regarding the second axis in our model, the question of self-organization, public housing cannot be assessed too positively, as the welfare traditions it represents are closely connected to notions of 
control and surveillance. In this light, it is not surprising that "many urban movements today have lost confidence" not only "in the market as the optimal (and equitable) provider" but also "in [...] the state as a trustworthy steward for collective consumption," as noted in the introduction to this volume. This points to the importance of non-state actors with respect to our topic.

\subsection{Self-organization in housing: The cooperative/third sector}

Although many types of providers of "third way" housing exist (e.g. charitable foundations, religious communities), cooperatives are the most important ones in German-speaking Europe. A cooperative (Genossenschaft in German), broadly understood, is an association of people with the purpose of governing a certain set of economic affairs collectively. This often entails access to and use of a shared resource. The cooperative model can thus be said to represent a classical institutional form to organize what we call the commons. A housing cooperative's members are commoners in that they are usually both the tenants and, collectively, the owners of the real estate. Furthermore, although membership is based on subscription for shares, the general assemblies of German and Swiss housing cooperatives usually operate on a one-person-one-vote basis, regardless of the value of each member's holdings.

Thus, other than in the housing provision arrangements discussed previously, (democratic) self-organization can be said to constitute a core element of the cooperative model. And since cooperatives' members obviously have no incentive to extract profits from themselves, it seems plausible that they manage their housing stock as a "non-commodified means of fulfilling people's needs." ${ }^{6}$ Yet depending on a cooperative's members' interests, they might, for instance, choose to sell a portion of the housing stock on the open market. The adherence of cooperatives to the purpose of sustained decommodification of their housing stocks depends, to some extent, on regulation prescribed from outside. This can, for example, come in the form of membership in an umbrella organization that oversees the observance of such basic rules. In Switzerland, there are two national associations of housing cooperatives, ${ }^{37}$ both of which ask their member organizations to comply with the principles laid down in the "Charter of Non-Profit Housing Providers" 38 which declares, among other things, that they are to provide affordable housing 
which remains withdrawn from speculation, that they use the cost rent model, and that they forgo profit-seeking. The relevance of this charter lies in the fact that adherence to it is widely used as a criterion for access to loans and other kinds of support from local and cantonal governments. It is also a requirement for receiving low-interest loans from two bank-like institutions supported by the Swiss Confederation that cater exclusively to cooperatives and other non-profit housing organizations. ${ }^{9}$ The legal concept of Gemeinnütrigkeit (non-profit status; literally "the quality of operating in favor of the common good") was, in contrast, never paramount in the German system of Objekttörderung, and the tax benefits connected to this status within the housing sector were abolished in $1989.4^{\circ}$

Recognizing only non-profit organizations as eligible for public support, the Swiss system of Trägerförderung ("financial support for providers") has clearly proven more up to the task of permanently decommodifying certain housing stocks. ${ }^{41}$ While only a marginal influence in most rural and suburban areas, Trägerförderung has been influential in creating a significant portion of non-profit housing in some cities. The most notable example is Zurich, Switzerland's largest city, where cooperative housing amounts to about 18 percent of the total stock, in addition to about 7 percent public housing, thus placing the total share of the "gemeinnützige" sector at a quarter (see Figure 3). In 201 I, voters approved a referendum obliging the city government to raise this percentage to a third by 2050. Apartments whose construction is directly subsidized by municipal (often supplemented by cantonal) funds, and which are therefore allocated on a needs basis, only make up a small part of cooperative estates. The city government's arguably most important instrument in supporting cooperatives is not a financial policy, but relates, again, to the property rights system. Through leasehold contracts (Baurechtsverträge), cooperatives can acquire city-owned land for very long periods, usually sixty years, for an annual rent. This title allows them to construct housing on these lots and to use them as collateral when raising the necessary capital for the project. The municipality, on the other hand, can facilitate the construction of affordable, non-profit housing without spending money of its own and without giving away public property irretrievably. 
4.3 Commoning by "hacking" the law?

Leasehold agreements are part of the property rights system and can govern the relation between any landowner and leaser, but they are by no means specifically designed to support cooperative housing. Zoning laws (which fall within the domain of public policies) are also not intended to require a percentage of affordable housing, as described above; their main purpose is rather to determine the permissible physical design of buildings - height, density etc. - in a given area. In order to achieve a measure of decommodification for certain housing stocks, these legal instruments were thus used in different ways than originally intended in the cases we have examined. This could be described as "hacking" the law ${ }^{42}-$ a concept that might become clearer once we introduce its arguably most accomplished application in the cooperative sector.

Many cooperatives in Germany and Switzerland became estranged from their social movement roots after World War II. Their way of managing property hardly differed from the commercial real-estate business, and their members were less keen on actively participating in the democratic structures of self-organization that were theoretically still in place. This stagnation was criticized by a new, post-i 968 generation of housing activists with ties to various tenants' struggles and protests against inconsiderate urban renewal projects; here squatting became one of the main protest methods. ${ }^{43}$ New organizational structures and legal models have since emerged among groups of squatters and former tenants that managed to become the lawful owners of their houses. The prime example is the Mietshäuser Syndikat, a network of collectively owned houses founded in 1992 which today comprises more than eighty individual housing initiatives all over Germany. It is technically not a cooperative as specified by German law, but a sort of elaborately checked and balanced federation of limited liability companies (Gesellschaften mit beschränkter Haftung, $\mathrm{GmbH})$. An association of the inhabitants of each house within the network holds half of the shares in the company in possession of the respective building. The other half is held by the Syndikat, enabling it to prevent the house from ever being resold, even if its inhabitants wanted to cash in on it. ${ }^{44}$ The idea behind this veto function is to preserve the houses as strictly decommodified common resources, regardless of the current users' intentions. This organizational model, we argue, is an excellent example of a clever "hack" of property rights, i.e. of "components [...] reduced $[. .$.$] to rebuild quite different systems with different arrangements of the$ 


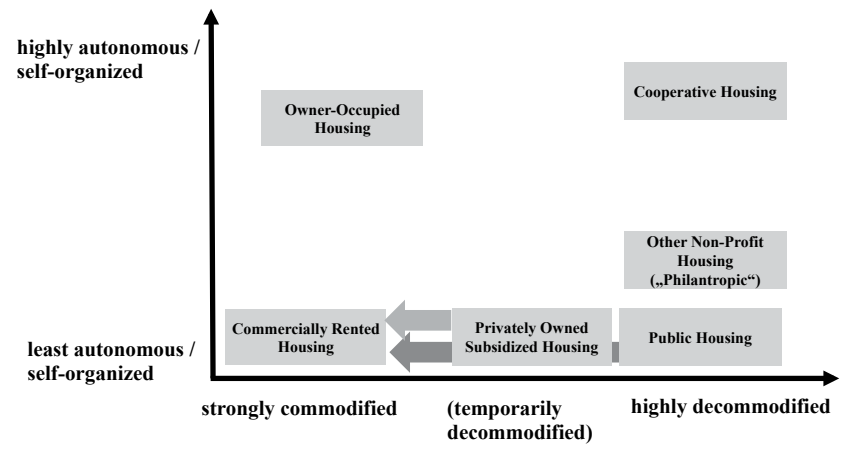

Figure 5. Types of housing tenure and provision - decommodification and self-organization.

pieces," 45 turning the "arch-capitalist" ${ }^{46}$ corporate structure of a GmbH into a vehicle for strictly non-profit projects. Considering this emphasis of access and usevalue as well as the high degree of autonomy that the individual inhabitants' groups enjoy within the network, the houses belonging to the Syndikat can thus be said to more clearly constitute a common resource than traditional cooperative housing.

\section{Conclusion}

In order to highlight the defining characteristics of the various types of housing tenure described in this chapter, we suggest, as mentioned, arranging them along two axes, one marking a commodification-decommodification scale, the other denoting the extent of self-organization. As we have seen, public housing may, for instance, be quite strongly decommodified, but it usually offers little room for tenants' self-organization, embodying instead hierarchical and centralist principles. As an owner-occupier, on the other hand, one might find a home to feel relatively independent in, but only as long as one can afford to pay the mortgage (Figure 5).

As we have attempted to show, and as Figure 5 illustrates, the crucial issue regarding the decommodification of housing stocks is the permanency of the measures taken: public policies can restrict certain incidents of ownership that enable the use of housing as a commodity, yet often only temporarily - be it because a subsidy scheme is set up to function in this way to begin with, as in the West German 
sozialer Wohnungsbau, or because of a policy change, typically privatization (cf. the arrows in figure 5). Only if the most powerful incidents of ownership lie with organizations that are perpetually bound, by internal and/or external regulation, to adhere to a non-profit strategy, can a housing stock be regarded as sustainably decommodified.

This diagram is obviously a simplification of the actual institutional diversity in this field, but it can help us reflect on the paths that commoning efforts can take nowadays. ${ }^{47}$ Cooperative organizations that correspond to commons principles as neatly as the Mietshäuser Syndikat are currently a niche phenomenon. Plainly put, this type of collective project, involving hours of voluntary work, thus requiring a rather specific lifestyle and cultural capital of a certain kind, is not for everyone. Yet even taking into account traditional, large cooperatives, it seems crucial not to fall into the trap of expecting the third sector to act as an adequate substitute for the state with regard to extensive social tasks. Municipalities will still have a role to play in providing affordable and secure housing to large parts of the population. However, as we have attempted to demonstrate, it may in fact be a paradoxically appropriate strategy in "late liberal" capitalism for both government and civil society actors to secure common resources effectively and sustainably not by conventional public policies, which can quickly be overturned, but rather by contractual means, making clever use of the property rights toolbox. Or, as Marcuse states, "the existing range of alternatives in use in market economies suggests that the attempt to expand them even further might not be an entirely quixotic endeavor." ${ }^{28}$

\section{Notes}

Cf. for instance Dan Andrews and Aida Caldera Sánchez, "The Evolution of Homeownership Rates in Selected OECD Countries: Demographic and Public Policy Influences," OECD Journal: Economic Studies $20 \mathrm{I}$ I, no. I: 2 I 2.

Please see the introduction to this volume.

3 Andreas Exner and Brigitte Kratzwald, Solidarische Ökonomie und Commons (Vienna: Mandelbaum, 20 I 2).

4 Silke Helfrich and Jörg Haas, "The Commons: A New Narrative for Our Times," in Genes, Bytes and Emissions: To Whom Does the World Belong?, Silke Helfrich, eds. (Berlin: Heinrich-Böll-Stiftung, 2009), I-I 5 .

5 Massimo De Angelis and Stavros Stavrides, "On the Commons: A Public Interview with Massimo De Angelis and Stavros Stavrides," e-flux 17 (20I I): I-I 7 .

6 Andrej Holm, "Wohnen als soziale Infrastruktur," Z. Zeitschrift marxistische Erneuerung 95 (2013): 44-57. 

(New York: Routledge, 2013), 26f.

8 Peter Marcuse, "Property Rights, Tenure and Ownership: Towards Clarity in Concept," in Social Rented Housing in Europe: Policy, Tenure and Design, Berth Danermark and Ingemar Elander, eds. (Delft: Delft University Press, I 994), 32.

9 Ibid., 25 f. Following Wesley N. Hohfeld, Fundamental Legal Conceptions as Applied in Judicial Reasoning (New Haven: Yale University Press, I9I6), Marcuse lists twelve key incidents of ownership with regards to housing, such as the "privilege to occupy and use for shelter" or the "right of profiting from a disposition."

Io This approach is partly based on Jean-David Gerber, Peter Knoepfel, Stéphane Nahrath, and Frédéric Varone, "Institutional Resource Regimes: Towards Sustainability Through the Combination of Property-Rights Theory and Policy Analysis," Ecological Economics 68, no. 3 (2008): 798-809.

I I Andrej Holm, “Wohnung als Ware: Zur Ökonomie und Politik der Wohnungsversorgung," Widersprüche I 2I (201 I): 20; author's translation (original: "Die Dekommodifizierung, also das Herauslösen der Wohnungsversorgung aus den Marktlogiken, kann dabei als Ziel und Maßstab für die Bewertung wohnungspolitischer Programme und Regelungen verstanden werden"); referring to Peter Williams and Neil Smith, "From 'Renaissance' to Restructuring: The Dynamics of Contemporary Urban Development," in Gentrification of the City, eds. Williams and Smith (Boston: Allen \& Unwin, I986), 204-224.

I 2 De Angelis and Stavrides, "On the Commons," 2; cf. the introduction to this volume.

I3 Ibid.

I4 Marcuse, "Property Rights," 26.

I5 Ibid., 29.

I6 Richard Arnott, "Housing Economies," in International Encyclopedia of the Social and Behavioral Sciences, Neil J. Smelser and Paul B. Baltes, eds. (Oxford: Elsevier, 2001), 6940.

17 John Doling, "De-commodification and Welfare: Evaluating Housing Systems," Housing, Theory and Society I6, no. 4 (I999): I6r.

i 8 In Marxist terms, housing thus provides a poignant example for the 'dual character' of goods, having use-value as well as exchange value, cf. Holm, "Wohnung als Ware."

I9 Andrews and Caldera Sánchez, "Homeownership Rates," 2 I 2.

20 Gøsta Esping-Andersen, The Three Worlds of Welfare Capitalism (Princeton: Princeton University Press, I990).

2I On the Spanish case, cf. Melissa García Lamarca's chapter in this volume, and Melissa García Lamarca, "Resisting Evictions Spanish Style," New Internationalist Magazine, April 2013, http://newint.org/ features/2013/04/OI/sparks-from-the-spanish-crucible/ (accessed September Io, 2014).

22 https://ergebnisse.zensus 20 I I.de/\#dyntable:statunit=wohnung;absRel=anzahl;ags = $\mathrm{I}$; ;agsaxis=X;yaxis=eigentum; https://www.stadt-zuerich.ch/content/dam/stzh/prd/Deutsch/Statistik/Publikationsdatenbank/jahrbuch/20I4/Tabellen/T_JB_2OI4_9_3.xlsx and http://www.statistik.at/web_ de/statistiken/wohnen_und_gebaeude/bestand_an_gebaeuden_und_wohnungen/022985.html (all accessed September 8, 2014)

23 Cf. for instance Andrej Holm and Dirk Gebhardt, eds., Initiativen für ein Recht auf Stadt: Theorie und Praxis städtischer Aneignungen (Hamburg: VSA, 201 I).

24 Kosten der Unterkunft ('housing costs') paid in addition to the Regelbedarf ('regular demand') as part of the Arbeitslosengeld II ("unemployment money II'), colloquially known as "Hartz IV" in Germany; Wobnkosten (also translatable as 'housing costs') paid in addition to the Grundbedarf ('basic demand') as part of the Sozialbilfe ('social welfare') in Switzerland. 
25 E.g. Andrej Holm, "Kosten der Unterkunft als Segregationsmotor: Befunde aus Berlin und Oldenburg," Informationen zur Raumentwicklung, 201 I , no. I I, 557-566.

26 Iris Marion Young, Justice and the Politics of Difference (Princeton: Princeton University Press, I 990), 239; cf. contribution by Kip, this volume.

27 Ulf Torgerson, quoted in Michael Harloe, The People's Home? Social Rented Housing in Europe and America (Oxford: Blackwell, I995), 2.

28 It would be beyond the scope of this chapter to go into the history of public and social housing in any depth, cf. Harloe, People's Home for an extensive international overview.

29 Björn Egner, "Wohnungspolitik seit I 945," Aus Politik und Zeitgeschichte, 20 I4, no. 20-2 I: I3.

30 Christian Donner, Wobnungspolitiken in der Europäischen Union (Vienna: Christian Donner, 2000), 200; cf. Andrej Holm, "Privatisierung des kommunalen Wohnungsbestandes", in Jabrbuch StadtRegion 2007/08: Arme reiche Stadt, Norbert Gestring, Herbert Glasauer, Christine Hannemann, Werner Petrowsky, and Jörg Pohlan, eds. (Opladen: Verlag Barbara Budrich, 2008), ı०2.

3 I Egner, "Wohnungspolitik," I 7.

32 Cf. Kotti \& Co, Sozialmieter.de and Selbstuniversität e.V., eds., Nichts läuft hier richtig: Informationen zum sozialen Wohnungsbau in Berlin (Berlin: 2014) for an excellent overview of these shortcomings from a local tenant activists' perspective.

33 Lukas Bühlmann and Niklaus Spori, "Förderung des gemeinnützigen Wohnungsbaus mit raumplanerischen Mitteln," Raum \& Umwelt iо, no. I (2010).

34 The paramount example in German-speaking Europe would be Vienna, where a quarter of the total housing stock is in the possession of the municipality and which we have therefore included in this overview in spite of otherwise omitting the Austrian case in this chapter.

35 Cf. Hartmut Häußermann, "Marktplatz oder Gemeinwesen? Der politische Inhalt der Verkaufspolitik und die Folgen für die Stadtentwicklung," Forum Wobnen und Stadtentwicklung 2006, no. 2: I 59-163; Andrej Holm, "Der Ausstieg des Staates aus der Wohnungspolitik," Planungsrundschau I 3 (2006): I03-I I3; Michael Voigtländer, "Die Privatisierung öffentlicher Wohnungen," Wirtschaftsdienst, 2007, no. I I: $748-753$.

36 De Angelis and Stavrides, "On the Commons," 2; cf. above.

37 Wobnbaugenossenschaften Schweiz - Verband der gemeinnützigen Wobnbauträger, the larger organziation, representing the labor/social-democratic tradition, and Wobnen Schweiz - Verband der Baugenossenschaften, of a more liberal heritage.

38 Charta der gemeinnützigen Wohnbauträger in der Schweiæ, http://www.wbg-schweiz.ch/downloads/I 7I/ gemeinsame_Charta_oI_or_I3_d_2877.pdf (accessed September 8, 2014).

39 The Federal Revolving Fund (Fonds de Roulement) which was funded by the Confederation and which the cooperatives' associations hold in trust, and the Bond Issuing Cooperative (BIC) for Non-Profit Housing (Emissionszentrale für Gemeinnützige Wohnbauträger, EGW), which borrows substantial means for cooperatives through the regular capital market with the Swiss Confederation acting as a guarantor; cf. Julie Lawson, "The Transformation of Social Housing Provision in Switzerland Mediated by Federalism, Direct Democracy and the Urban/Rural Divide," European Journal of Housing Policy 9, no. I (2009). In addition, the Wobnbaugenossenschaften Schweiz operates a fund of its own.

40 Volker Dorn, "Changes in the Social Rented Sector in Germany," Urban Studies I 2, no. 4 ( 1 997): 469.

4I A similar system was in fact in place in Germany during the Weimar Republic period, cf. e.g. Hartmut Häußermann and Walter Siebel, Soziologie des Wohnens: Eine Einführung in Wandel und Ausdifferenzierung des Wohnens (Weinheim/Munich: Juventa, I996), I 3 ff.

42 We are indebted to Dubravka Sekulić for introducing us to this fitting metaphor.

43 Concerning these movements, an exemplary case study for Zurich was authored by Thomas Stahel, Wo-Wo-Wonige: Stadt- und wohnpolitische Bewegungen in Zürich nach 1968 (Zurich: Paranoia City, 2006). . 
44 Cf. Stefan Rost, "Das Mietshäuser Syndikat," in Commons - Für eine neue Politik jenseits von Markt und Staat, eds. Silke Helfrich and Heinrich-Böll-Stiftung (Bielefeld: Transcript, 20 I 2), 285-287; Stefan Rost, "Die beste Genossenschaft ist gar keine: Klaus-Novy-Preis 20 I 2 für das Mietshäuser Syndikat," Freihaus I 8 (201 2): 7-9; Peter Ache and Micha Fedrowitz, "The Development of Co-Housing Initiatives in Germany," Built Environment 38, no. 3 (201 2): 399. The Syndikat itself is again organized as another $\mathrm{GmbH}$ with just one shareholder, an association whose members are, in turn, the various inhabitants' associations along with individuals who support the network's basic idea.

45 Marcuse, Property Rights, 29.

46 Rost, Genossenschaft, 9.

47 Cf. also Stuart Hodkinson, "The Return of the Housing Question”, Ephemera I 2, no. 4 (201 2): 423-444.

48 Marcuse, Property Rights, 29. 